\title{
Nutritional Supplement Use and Age-Related Macular Degeneration
}

\author{
Amy C. Y. Lo and Ian Y. Wong \\ Eye Institute, The University of Hong Kong \\ Hong Kong
}

\section{Introduction}

Age-related macular degeneration (AMD) is a leading cause of irreversible visual impairment and blindness in the aging population ${ }^{1}$. Yet, individuals with AMD have limited treatment options. Given the high prevalence and considerable public health burden, it is essential to understand the etiology and pathogenesis of AMD.

AMD is a multifactorial disease, with complex genetics and confounding environmental risk factors. The etiology of AMD still remains unknown, but oxidative stress to the retina and the retinal pigment epithelium (RPE) is one of the leading hypotheses in AMD pathogenesis.

\section{Oxidative stress and AMD}

Oxidative stress and the cellular damages caused by reactive oxygen species (ROS) has been implicated in aging and age-related eye diseases ${ }^{2}$. Most intracellular ROS are derived from the mitochondria in the electron transport chain. During fuel metabolism, oxygen consumption and ATP synthesis in the mitochondria, electrons are shuffled in sequential reduction and oxidation reactions in the electron transport chain. Yet, these reactions are not $100 \%$ efficient; electrons may "leak" out and result in the formation of ROS. ROS are highly reactive and unstable oxygen-containing atoms, ions, or molecules such as hydroxyl radical $(\mathrm{OH} \cdot)$, superoxide anion $\left(\mathrm{O}_{2}^{--}\right)$and hydrogen peroxide $\left(\mathrm{H}_{2} \mathrm{O}_{2}\right)$. Due to the presence of the "unpaired" electron in the outer shell, ROS are very unstable. In trying to achieve stability, ROS will then participate in further reduction and oxidation reactions, oxidizing target molecules and resulting in generation of other free radicals by chain reaction.

Oxidative damages by ROS affect DNA and lipids inside the cell. Earlier senescence, which may be related to shortening of telomeric DNA, occurs after oxidative damage ${ }^{3-6}$. Oxidative damage also results in point mutations and deletions in mitochondrial DNA 7. In fact, mitochondrial DNA is more susceptible to ROS-induced damage than nuclear DNA ${ }^{8}$. As for lipids, ROS causes oxidation of lipid in a process called lipid peroxidation. The polyunsaturated fatty acids, a common and significant component of cell membrane, are particularly vulnerable to oxidation by ROS as a result of their many conjugated double bonds. Oxidation of polyunsaturated fatty acids results in the formation of reactive aldehyde intermediates which are toxic to the cell 9 . 
The retina is a structure that is particularly susceptible to oxidative damage by ROS. Firstly, the retina has the highest oxygen consumption in the body ${ }^{10}$. In addition, constant exposure to incoming light in the retina can lead to photo-oxidation. The high oxygen consumption and high light exposure in the retina may in turn generate ROS. Moreover, the retina has a high lipid content, with abundant polyunsaturated fatty acids in the photoreceptor outer segments which are most prone to lipid peroxidation. In the neighborhood of photoreceptors are the RPE cells. Besides providing metabolic support to the photoreceptors, they also phagocytose the constantly shed parts of the photoreceptor outer segments. All these factors contribute to the susceptibility of the retina and RPE to oxidative stress.

With age, the susceptibility to oxidative damage in the retina increases. Aged rat retina showed decreased GSH-Px and catalase activities, which are related to increased lipid peroxidation with age ${ }^{11}$. In particular, RPE cells accumulate lipofuscin granules during life. Lipofuscin granules are lysosomal residual bodies containing undigested end products from phagocytosis of photoreceptor outer segments ${ }^{12}$. It was estimated that lipofuscin can occupy up to $19 \%$ of RPE cytoplasmic volume by the age of 80 when compared with only $1 \%$ during the first decade of life ${ }^{13}$. Lipofuscin has been shown to contain toxic substances, such as retinoids (products of the visual cycle) and oxidized proteins ${ }^{14}$. Lipofuscin was also able to reduce RPE lysosomal and antioxidant activity ${ }^{15}$. In vitro studies using porcine RPE cells showed that visible light irradiation can degrade RPE melanosomes, reduce melanin amount and increase ROS production, changes that also occur in human RPE melanosomes with aging ${ }^{16}$.

\section{Nutritional supplements and AMD}

Oxidative stress has a recognized role in aging and AMD; treatments for AMD are therefore aimed at reducing oxidative stress-induced damage within the retina and RPE cells. This can be approached in two ways, either by decreasing the source of oxidative stress or by increasing the defense against oxidative stress. Among them, a tempting measure in lowering oxidative damage would be by dietary antioxidant supplementation. Data from observational studies have supported a link between nutritional factors with antioxidant properties and risks of AMD 17,18. Carotenoids, vitamin C and vitamin E with their antioxidant properties have been identified as having a potentially protective role. Other nutrients such as zinc and omega-3 fatty acids have been shown to be associated with reduced risk of AMD. Recently, $B$ vitamins (folic acid, $B_{6}$ and $B_{12}$ ) have also been proposed to provide protection by a non-oxidative mechanism. Another nutritional supplement that has gained interest recently is the extracts from a group of fruit, berries.

Common nutrition supplements include:

1. AREDS and AREDS-type formulation

2. Carotenoids ( $\beta$-carotene, lutein and zeaxanthin)

3. Vitamin C (L-ascorbic acid)

4. Vitamin E ( $\alpha$-tocopherol))

5. Zinc

6. Omega-3 Long chain polyunsaturated fatty acids

7. B vitamins

8. Berry extracts 
A summary of studies investigating the effect of nutritional supplements on the prevention and progression of AMD is shown in Tables 1 and 2.

\begin{tabular}{|c|c|c|c|c|}
\hline & Study & \begin{tabular}{|l|} 
Nutrients \\
investigated
\end{tabular} & \begin{tabular}{|l} 
participants \\
(number; age)
\end{tabular} & Follow-up \\
\hline \multicolumn{5}{|l|}{ Randomized trials } \\
\hline Teikari $19988^{43}$ & $\begin{array}{l}\text { Alpha-tocopherol and } \\
\text { beta-carotene study } \\
\text { (ATBC) }\end{array}$ & $\begin{array}{l}\text { beta-carotene; } \\
\text { vitamin E }\end{array}$ & $\begin{array}{l}\text { Finland }(941 ; \geq 65 \\
\text { years old) }\end{array}$ & $\begin{array}{l}\text { 6-year } \\
\text { prevalence }\end{array}$ \\
\hline Taylor 200274 & $\begin{array}{l}\text { Vitamin E, cataract, } \\
\text { and age related } \\
\text { maculopathy trial } \\
\text { (VECAT) }\end{array}$ & vitamin E & $\begin{array}{l}\text { Australia }(1,193 ; 55- \\
80 \text { years old })\end{array}$ & $\begin{array}{l}\text { 4-year } \\
\text { incidence }\end{array}$ \\
\hline Christen 2009132 & $\begin{array}{l}\text { Women's } \\
\text { Antioxidant and } \\
\text { Folic Acid } \\
\text { Cardiovascular } \\
\text { Study (WAFACS) }\end{array}$ & folic acid/ $\mathrm{B}_{6} / \mathrm{B}_{12}$ & $\begin{array}{l}\text { Female health care } \\
\text { professionals } \\
\text { in USA } \\
(5,442 ; \geq 40 \text { years })\end{array}$ & Av 7.3 years \\
\hline Christen $2010^{75}$ & $\begin{array}{l}\text { Women's Health } \\
\text { Study (WHS) }\end{array}$ & vitamin E & $\begin{array}{l}\text { Female health } \\
\text { professionals } \\
\text { in USA } \\
(39,876 ; \geq 45 \text { years })\end{array}$ & $\begin{array}{l}\text { Av } 10 \text { years } \\
\text { follow up }\end{array}$ \\
\hline Weigert $2011{ }^{61}$ & $\begin{array}{l}\text { Lutein Intervention } \\
\text { Study Austria } \\
\text { (LISA) }\end{array}$ & lutein & 126 AMD patients & $\begin{array}{l}\text { 6-month } \\
\text { follow up }\end{array}$ \\
\hline \multicolumn{5}{|c|}{ Population-based studies } \\
\hline $\begin{array}{l}\text { VandenLangenberg } \\
\text { et al } 23\end{array}$ & Beaver Dam study & $\begin{array}{l}\text { alpha-carotene; beta- } \\
\text { carotene; beta } \\
\text { cryptoxanthin; lutein } \\
\text { + zeaxanthin; } \\
\text { lycopene; vitamin E; } \\
\text { zinc; fruit and } \\
\text { vegetables; } \\
\text { supplements }\end{array}$ & $\begin{array}{l}\text { USA }(1,709 ; 43-84 \\
\text { years old) }\end{array}$ & $\begin{array}{l}\text { 5-year } \\
\text { incidence }\end{array}$ \\
\hline Smith 2000107 & $\begin{array}{l}\text { The Blue Mountains } \\
\text { Eye Study (BMES) }\end{array}$ & dietary fat, fish & $\begin{array}{l}\text { Australia (3654; } \geq 49 \\
\text { years old) }\end{array}$ & \\
\hline Cho 200188 & $\begin{array}{l}\text { Nurses' Health Study } \\
\text { (NHS) and Health } \\
\text { Professional Follow- } \\
\text { up Study (HPFS) }\end{array}$ & zinc & $\begin{array}{l}\text { Health } \\
\text { professionals in } \\
\text { USA (104,208: } \\
66,572 \text { women, } \\
37,636 \text { men; } \geq 50 \\
\text { years old) }\end{array}$ & $\begin{array}{l}\text { 8-10 year } \\
\text { incidence }\end{array}$ \\
\hline Cho 2001108 & $\begin{array}{l}\text { Nurses' Health Study } \\
\text { (NHS) and Health } \\
\text { Professional Follow- } \\
\text { up Study (HPFS) }\end{array}$ & Dietary fat & $\begin{array}{l}\text { Health } \\
\text { professionals in } \\
\text { USA (72,489: } 42,743 \\
\text { women, } 29,746 \text { men; } \\
\geq 50 \text { years old) }\end{array}$ & \\
\hline Heuberger $20011^{145}$ & \begin{tabular}{|l|} 
Third National \\
Health and Nutrition \\
Examination Study \\
(NHANES III) \\
\end{tabular} & Dietary fat & $\begin{array}{l}\text { USA }(11,448 ; 40-79 \\
\text { years old) }\end{array}$ & \\
\hline
\end{tabular}




\begin{tabular}{|c|c|c|c|c|}
\hline & Study & $\begin{array}{l}\text { Nutrients } \\
\text { investigated }\end{array}$ & $\begin{array}{l}\text { participants } \\
\text { (number; age) }\end{array}$ & Follow-up \\
\hline Flood 200244 & $\begin{array}{l}\text { The Blue Mountains } \\
\text { Eye Study (BMES) }\end{array}$ & $\begin{array}{l}\text { alpha-carotene; beta- } \\
\text { carotene; beta } \\
\text { cryptoxanthin; lutein } \\
\text { + zeaxanthin; } \\
\text { lycopene; vitamin A; } \\
\text { vitamin C; zinc; } \\
\text { supplements } \\
\end{array}$ & $\begin{array}{l}\text { Australia }(1,989 ; \geq 49 \\
\text { years old })\end{array}$ & $\begin{array}{l}5 \text {-year } \\
\text { incidence }\end{array}$ \\
\hline Cho, 200452 & $\begin{array}{l}\text { Nurses' Health Study } \\
\text { and men in the } \\
\text { Health Professionals } \\
\text { Follow-up Study }\end{array}$ & $\begin{array}{l}\text { alpha-carotene; beta- } \\
\text { carotene; beta } \\
\text { cryptoxanthin; lutein } \\
\text { + zeaxanthin; } \\
\text { lycopene; vitamin A; } \\
\text { vitamin C; vitamin E; } \\
\text { fruits and vegetables; } \\
\text { supplements }\end{array}$ & $\begin{array}{l}\text { Health } \\
\text { professionals in } \\
\text { USA }(118,428 ; \geq 50 \\
\text { years old })\end{array}$ & $\begin{array}{l}12-18 \text { year } \\
\text { incidence }\end{array}$ \\
\hline van Leeuwen 2005 & Rotterdam Eye Study & $\begin{array}{l}\text { alpha-carotene; beta- } \\
\text { carotene; beta } \\
\text { cryptoxanthin; lutein + } \\
\text { zeaxanthin; lycopene; } \\
\text { vitamin A; vitamin C; } \\
\text { vitamin E; zinc }\end{array}$ & $\begin{array}{l}\text { Netherlands }(4,170 ; \\
\geq 55 \text { years old })\end{array}$ & $\begin{array}{l}\text { Mean 8-year } \\
\text { follow-up }\end{array}$ \\
\hline Chua $20066^{110}$ & $\begin{array}{l}\text { The Blue Mountains } \\
\text { Eye Study (BMES) }\end{array}$ & $\begin{array}{l}\text { omega-3 fatty acid; } \\
\text { fish }\end{array}$ & \begin{tabular}{|l|} 
Australia $(3654 ; \geq 49$ \\
years old)
\end{tabular} & \begin{tabular}{|l|}
$\begin{array}{l}5-y e a r \\
\text { incidence }\end{array}$ \\
\end{tabular} \\
\hline Moeller 200653 & $\begin{array}{l}\text { Carotenoids in } \\
\text { Age-related } \\
\text { Eye Disease } \\
\text { Study (CAREDS) }\end{array}$ & $\begin{array}{l}\text { lutein + zeaxanthin; } \\
\text { fruit and vegetable }\end{array}$ & $\begin{array}{l}\text { Women's Health } \\
\text { Initiative } \\
(1,787 ; 50 \text { to } \\
79 \text { years old), } \\
\text { women only }\end{array}$ & $\begin{array}{l}6 \text { year } \\
\text { prevalence }\end{array}$ \\
\hline Delcourt 2007112 & $\begin{array}{l}\text { Pathologies Oculaires } \\
\text { Liees a IAge } \\
(\text { POLANUT) }\end{array}$ & $\begin{array}{l}\text { total fish; white fish; } \\
\text { fatty fish }\end{array}$ & $\begin{array}{l}\text { France }(832 ; \geq 70 \\
\text { years old })\end{array}$ & \\
\hline Augood $20088^{114}$ & EUREYE & DHA; EPA; oily fish & Europe $(4,753)$ & \\
\hline Cho $2008{ }^{54}$ & \begin{tabular}{|l|} 
Nurses' health Study \\
and Health \\
Professionals Follow- \\
up Study
\end{tabular} & lutein + zeaxanthin & $\begin{array}{l}(113,058: 71,494 \\
\text { women and } 41,564 \\
\text { men; } \geq 50 \text { years old })\end{array}$ & $\begin{array}{l}\text { Up to } 16 \text { years } \\
\text { in men, Up to } \\
18 \text { years in } \\
\text { women }\end{array}$ \\
\hline Wang $2008{ }^{117}$ & $\begin{array}{l}\text { The Blue Mountains } \\
\text { Eye Study (BMES) }\end{array}$ & fish & \begin{tabular}{|l|} 
Australia $(1,881 ; \geq 49$ \\
years old; $C F H$ \\
genotype)
\end{tabular} & 10 year \\
\hline Tan 200845 & $\begin{array}{l}\text { The Blue Mountains } \\
\text { Eye Study (BMES) }\end{array}$ & $\begin{array}{l}\text { alpha-carotene; beta- } \\
\text { carotene; beta } \\
\text { cryptoxanthin; lutein } \\
\text { + zeaxanthin; } \\
\text { lycopene; vitamins A; } \\
\text { vitamin C; vitamin } \\
\text { E; iron; zinc } \\
\end{array}$ & $\begin{array}{l}\text { Australia }(2,454 ; \geq 49 \\
\text { years old })\end{array}$ & $\begin{array}{l}\text { Mean } 5.1 \text { years } \\
\text { and } 10.5 \text { years }\end{array}$ \\
\hline Tan 2009116 & $\begin{array}{l}\text { The Blue Mountains } \\
\text { Eye Study (BMES) }\end{array}$ & $\begin{array}{l}\text { omega-3 fatty acid; } \\
\text { fish }\end{array}$ & $\begin{array}{l}\text { Australia }(3654 ; \geq 49 \\
\text { years old) }\end{array}$ & $\begin{array}{l}10 \text {-year } \\
\text { incidence }\end{array}$ \\
\hline Ho 201191 & The Rotterdam Study & $\begin{array}{l}\text { beta-carotene; } \\
\text { lutein/zeaxanthin; } \\
\text { DHA; EPA; zinc; }\end{array}$ & $\begin{array}{l}\text { Netherlands }(2,167 ; \\
\geq 55 \text { years old; } C F H \\
\text { and } \\
\text { LOC387715/ARMS2 } \\
\text { genotype) }\end{array}$ & Mean 8.6 years \\
\hline
\end{tabular}




\begin{tabular}{|c|c|c|c|c|}
\hline & Study & $\begin{array}{l}\text { Nutrients } \\
\text { investigated }\end{array}$ & $\begin{array}{l}\text { participants } \\
\text { (number; age) }\end{array}$ & Follow-up \\
\hline \multicolumn{5}{|l|}{ Retrospective study } \\
\hline $\begin{array}{l}\text { Mares-Perlman } \\
1995\end{array}$ & $\begin{array}{l}\text { Beaver Dam Study } \\
\text { and Nutritional } \\
\text { Factors in Eye } \\
\text { Disease Study }\end{array}$ & $\begin{array}{l}\text { total fat; } \\
\text { saturated fat; } \\
\text { oleate; linoleate; } \\
\text { cholesterol; } \\
\text { seafood }\end{array}$ & $\begin{array}{l}\text { USA }(2,152 ; 45-84 \\
\text { years old) }\end{array}$ & \\
\hline Klein 200890 & AREDS & AREDS, zinc & $\begin{array}{l}\text { USA (876; CFH and } \\
\text { LOC387715/ARMS2 } \\
\text { genotype) }\end{array}$ & \\
\hline \multicolumn{5}{|l|}{ Case controlled study } \\
\hline Seddon $2006{ }^{111}$ & $\begin{array}{l}\text { US Twin Study of } \\
\text { Age-Related Macular } \\
\text { Degeneration } \\
\end{array}$ & $\begin{array}{l}\text { omega-3 fatty acids; } \\
\text { fish }\end{array}$ & $\begin{array}{l}\text { USA (681 twins; } \\
\text { male only) }\end{array}$ & \\
\hline $\begin{array}{l}\text { SanGiovanni } 2007 \\
113\end{array}$ & AREDS & $\begin{array}{l}\text { DHA; } \\
\text { omega-3 fatty acids; } \\
\text { fish }\end{array}$ & $\begin{array}{l}\text { USA }(4,519 ; 60-80 \\
\text { years old })\end{array}$ & \\
\hline \multicolumn{5}{|l|}{ Cross-sectional study } \\
\hline Chiu 2009146 & AREDS & $\begin{array}{l}\text { DHA; EPA; } \\
\text { lutein/zeaxanthin; } \\
\text { vitamin C; vitamin E; } \\
\text { zinc }\end{array}$ & USA $(4,003)$ & \\
\hline
\end{tabular}

Table 1. Studies investigating nutritional supplements in the prevention of AMD

\begin{tabular}{|c|c|c|c|c|}
\hline & Study & Nutrients investigated & $\begin{array}{l}\text { participants } \\
\text { (number; age) }\end{array}$ & $\begin{array}{l}\text { Treatment } \\
\text { duration }\end{array}$ \\
\hline Newsome $1988{ }^{24}$ & & zinc & $\begin{array}{l}\text { USA (151: } 56 \text { men, } 95 \\
\text { women; } 42-89 \text { years } \\
\text { old) }\end{array}$ & $12-24$ months \\
\hline Stur 199687 & & Zinc & $\begin{array}{l}\text { Austria (112: } 48 \text { men, } \\
64 \text { women; } \geq 50 \text { years } \\
\text { old) }\end{array}$ & 24 months \\
\hline AREDS 19 & & $\begin{array}{l}\text { beta-carotene; vitamin } \\
\text { C; vitamin E; copper; } \\
\text { zinc }\end{array}$ & $\begin{array}{l}\text { USA }(3640,56 \% \\
\text { women; average } 69 \\
\text { years old) }\end{array}$ & 6 years \\
\hline Seddon 2001109 & & Dietary fat, fish & $\begin{array}{l}\text { USA }(349 ; 55-80 \\
\text { years old) }\end{array}$ & \\
\hline Richer 200455 & $\begin{array}{l}\text { Veterans LAST } \\
\text { study (Lutein } \\
\text { Antioxidant } \\
\text { Supplementation } \\
\text { Trial)LAST }\end{array}$ & $\begin{array}{l}\text { lutein } \\
\text { /antioxidants/vitamins } \\
\text { and minerals broad } \\
\text { spectrum } \\
\text { supplementation } \\
\text { formula }\end{array}$ & $\begin{array}{l}\text { USA (90: } 86 \text { men, } 4 \\
\text { women) }\end{array}$ & 12 months \\
\hline $\begin{array}{l}\text { SanGiovanni } \\
2008115\end{array}$ & AREDS & omega-3 fatty acid; fish & USA $(2,132)$ & \\
\hline Weigert 201161 & $\begin{array}{l}\text { Lutein Intervention } \\
\text { Study Austria } \\
\text { (LISA) }\end{array}$ & lutein & $\begin{array}{l}\text { Austria (126 AMD } \\
\text { patients) }\end{array}$ & 6 months \\
\hline
\end{tabular}

Table 2. Studies investigating nutritional supplements in the progression of AMD 


\subsection{AREDS and AREDS-type formulation}

The Age-Related Eye Disease Study (AREDS) was a clinical trial sponsored by the National Eye Institute ${ }^{19}$. This was to date the largest prospective randomized controlled trial to investigate the effect of an active supplement formula on the risk of development of AMD. The dosages of the supplements were at a high-than-normal level, because it was considered a form of active treatment, instead of a simple supplement pill. There were a total of 3,640 subjects, being monitored for an average of 6.3 years. Each subject was given either the AREDS formula, or placebo, to be taken on a twice-daily basis. Main components of the AREDS formula are vitamin A, vitamin C, vitamin E, and zinc. These were chosen because of their anti-oxidative abilities ${ }^{20-25}$. When compared with the Dietary Reference Intake (DRI) issued by the Institute of Medicine, US National Academy, the dosage of ingredients in the AREDS formula was at a much higher level ${ }^{26}$. For instance, the dosage of vitamin $C$ in the AREDS formula was $500 \mathrm{mg} /$ day, while that of the DRI was only $90 \mathrm{mg}$ per day. As far as vitamin $C$ was concerned, one has to take at least 7 to 8 oranges per day, just to match up with what is provided by the AREDS pill 27. A comparison of the dosage in AREDS formulation with common fruits is given in Table 3.

\begin{tabular}{|l|l|l|l|l|l|l|l|}
\hline Nutrients & Unit & AREDS & DRI $^{*}$ & Apple $^{\#}$ & Orange $^{\#}$ & Banana $^{\#}$ & Blueberry $^{\# 1}$ \\
\hline Vitamin A@ & $\begin{array}{l}\text { International } \\
\text { Unit (IU) }\end{array}$ & 5000 & 3000 & 54 & 225 & 64 & 22 \\
\hline Vitamin C & $\begin{array}{l}\text { milligram } \\
(\mathrm{mg})\end{array}$ & 500 & 90 & 4.6 & 53.2 & 8.7 & 0.7 \\
\hline Vitamin E & $\mathrm{mg}$ & 400 & 15 & 0.18 & 0.1 & 0.1 & 0.23 \\
\hline Zinc & $\mathrm{mg}$ & 80 & 11 & 0.04 & 0.07 & 0.15 & 0.1 \\
\hline Copper & $\mathrm{mg}$ & 2 & 0.9 & 0.027 & 0.045 & 0.078 & 0.12 \\
\hline $\begin{array}{l}\text { Lutein }+ \\
\text { Zeaxanthin }\end{array}$ & $\begin{array}{l}\text { microgram } \\
(\mu \mathrm{g})\end{array}$ & None & No data $* *$ & 29 & 129 & 22 & 33 \\
\hline
\end{tabular}

@ Vitamin A as beta-carotene

* Dietary Reference Intakes from the Institute of Medicine

** 2.0-2.3 mg/day for men and 1.7-2.0 mg/day for women in United States

(Food and Nutrition Board, 2001)

\# Nutrient contents of common fruits are expressed per 100 grams

Table 3. Dosages of the Age-Related Eye Disease Study (AREDS) type formulas in comparison to common fruit items

After categorizing the subjects according to their macular status (Table 4), they were then monitored serially with fundus photographs. Results of the AREDS were first released in 2001. It showed a $25 \%$ risk reduction in progression to advanced AMD, for category 3 and 4 subjects only. For other subjects, i.e. those under category 1 and 2, results were not statistically significant. In the US, $80 \%$ of those over 70 years of age fall under either category 1 or 2 28. Hence, the protection offered by the AREDS formula may not be applicable to all. Therefore, it was only recommended to high-risk individuals (those under category 3 or 4 ).

Risk associated with regular intake of the AREDS formula was of particular concern, mainly because it was meant for long-term use. In particular, the risk of regular intake of such a high level of vitamins and minerals was unknown. Potentially, vitamin A (in the form of 
beta-carotene) may be associated with an increased risk of lung cancer in smokers; vitamin $\mathrm{C}$ may cause renal stones; vitamin $\mathrm{E}$ may be associated with increased risk of hemorrhagic stroke; zinc can cause anemia, stomach upset, and may reduce serum high-density lipoprotein level.

\begin{tabular}{|l|l|l|l|}
\hline & Brief description & Clinical features & Visual acuity \\
\hline Category 1 & No AMD in both eyes & $\begin{array}{l}<5 \text { small drusen in one or } \\
\text { both eyes }\end{array}$ & $\begin{array}{l}20 / 32 \text { or better in both } \\
\text { eyes }\end{array}$ \\
\hline Category 2 & $\begin{array}{l}\text { Multiple small or } \\
\text { in one or both eyes } \\
\text { one or both eyes } \\
\text { Pigment abnormalities in } \\
\text { one or both eyes }\end{array}$ & $\begin{array}{l}\text { 20/32 or better in both } \\
\text { eyes }\end{array}$ \\
\hline Category 3 & $\begin{array}{l}\text { Absence of advanced } \\
\text { AMD in both eyes } \\
\text { drusen } \\
\text { Geographic atrophy } \\
\text { Features not involving } \\
\text { central macula }\end{array}$ & $\begin{array}{l}\text { 20/32 or better in better } \\
\text { eye }\end{array}$ \\
\hline Category 4 & $\begin{array}{l}\text { Advanced AMD in one } \\
\text { eye }\end{array}$ & $\begin{array}{l}\text { geographic atrophy in } \\
\text { worse eye } \\
\text { No such features in better } \\
\text { eye }\end{array}$ & 20/32 or better in better \\
eye
\end{tabular}

Key: small drusen, $<63 \mathrm{um}$ in diameter (disc diameter around $1500 \mathrm{um}$ ); intermediate drusen, 63-124 um in diameter; large drusen, $>125$ um in diameter; pigment abnormalities refer to either hyperpigmentation or depigmentation 27

Table 4. Categorization of AMD according to AREDS guidelines

However, observations from the AREDS cohort failed to show any statistically significant serious side effects as mentioned above. Documented minor side effects included 1) increased genitourinary symptoms; 2) increased self-reported anemia; and 3) yellow discoloration of skin due to high level of vitamin A. Self-reported anemia was not correlated with any genuine reduction in blood hematocrit level. Smokers in the AREDS were discouraged from smoking, therefore whether the risk of lung cancer was increased was not being addressed. However, this has already been confirmed in two other trials 29,30. Hence, all smokers should be discouraged from smoking before the commencement of the AREDS formula. If he or she is not willing to quit smoking, the risk of having lung cancer may outweigh the potential benefit in AMD protection.

In general, the AREDS formula was deemed safe and effective, in selected high-risk individuals 31 . Inadequacy of the AREDS formula was that it did not include other potential ingredients such as lutein, zeaxanthin, and omega-3 fatty acid, which are also of particular interest due to their antioxidant abilities. In view of this, the National Eye Institute has launched the Age-Related Eye Disease Study 2 (AREDS2) in 2006, in hope to fill up the knowledge in this gap 32,33 . In the AREDS2 formula, lutein, zeaxanthin, and omega-3 fatty acid have been added to the existing AREDS formula, and vitamin A was removed, mainly due to the potential risk associated with lung cancer. Results of the AREDS2 are expected to be available in 2012. Until then, the AREDS formula remains the only evidenced-based formula to reducing the risk of development of advanced AMD. 


\subsection{Carotenoids ( $\beta$-carotene, lutein and zeaxanthin)}

Carotenoids are organic pigments naturally occurring in plants as well as in some algae, fungus and bacteria. Animals generally cannot synthesize carotenoids; they have to obtain carotenoids in their diet. There are two classes of carotenoids, xanthophylls (which contain oxygen) and carotenes (which are purely hydrocarbons, and contain no oxygen) accounting for over 600 known carotenoids. A well known carotene is beta-carotene, the pigment that makes carrots orange. Interestingly, there are only two carotenoids that are present in the human retina 34,35, namely lutein [(3R,3'R,6'R)-beta,epsilon-Carotene-3,3'-diol] and its stereoisomer, zeaxanthin [(3R,3'R)-beta,beta-Carotene-3,3'-diol]. These carotenoids are enriched in the macula in high concentrations, thus giving the macula its yellowish color.

In human, four carotenoids including beta-carotene, alpha-carotene, gamma-carotene, and beta-cryptoxanthin can be converted into retinal, which is an important molecule in the photo-transduction pathway and therefore vision. Carotenoids can also absorb light and act as antioxidants by scavenging ROS such as $\mathrm{O} 2$ and peroxyl radicals ${ }^{36}$. In particular, two xanthophylls, lutein and zeaxanthin, have been shown to absorb the damaging blue light 36 as well as protect the retina ${ }^{37}$ and retinal ganglion cells ${ }^{38}$ from oxidative damage in vitro. In animal studies, lutein protected the inner retina against acute retinal ischemia/reperfusion injury due to its antioxidant properties ${ }^{39}$.

Due to their antioxidant properties and blue light-filtering effects, the association of carotenoids with risk of AMD was explored. There have been conflicting results. Decreased risk of neovascular AMD has been found to be associated with higher levels of carotenoids in the serum samples ${ }^{40}$. In monkeys, feeding a xanphophyll-free diet has been shown to promote drusen formation ${ }^{41}$. In an early study based on National Health and Nutrition Examination Survey I data, an inverse association between the consumption of fruits and vegetables rich in pro-vitamin A carotenoids and the prevalence of AMD was demonstrated 22. In the Beaver Dam Eye Study, VandenLangenberg et al also found a significant but modest inverse association between intake of pro-vitamin A carotenoids and the incidence of large drusen ${ }^{23}$. Later studies using the AREDS formulation suggested a beneficial effect of beta-carotene ${ }^{19}$. The Rotterdam population-based study also reported a high dietary intake of beta-carotene together with vitamins $C$ and $E$ and zinc reduced the risk of AMD in elderly individuals ${ }^{42}$. A 35\% reduced risk of AMD was observed when an above-median intake of these 4 nutrients was given.

On the other hand, opposing results were obtained from other clinical trials and populationbased studies. The Alpha-Tocopherol and Beta-Carotene (ATBC) Study in Finland assessed the involvement of beta-carotene in occurrence of AMD among smoking males ${ }^{43}$. Over 29,000 smoking males aged 50 to 69 years were given alpha-tocopherol ( $50 \mathrm{mg} /$ day), betacarotene $(20 \mathrm{mg} /$ day), both of these, or placebo randomly. After 5 to 8 years of supplementation, Teikari et al found no beneficial effect of long-term beta-carotene supplementation on the incidence of AMD. The Blue Mountains Eye Study also reported no associations between beta-carotene intake and 5-year incidence of AMD 44. This is a population-based study including 1,989 individuals who finished a food frequency questionnaire. This questionnaire assessed the baseline intake of nutrients including alphacarotene, beta-carotene, beta-cryptoxanthin, lutein and zeaxanthin, lycopene, retinol, vitamin A, vitamin C, and zinc. For beta-carotene, Teikari et al suggested no evidence of protection by beta-carotene on the 5-year incidence of AMD. Further studies in the same 
population after 10-year of follow-up showed some interesting results. Instead of showing no effect of beta-carotene in AMD, Tan et al actually reported an increased risk of neovascular AMD with increasing beta-carotene intake 45 . The authors found that increasing beta-carotene intake, either from diet alone or diet plus supplementation, was associated with higher risk neovascular AMD. This association also existed when the smoking status of the individuals was adjusted.

In fact, one has to bear in mind about the possible harmful effect of beta-carotene supplementation. Apart from the skin coloration, changes in scotopic b-wave during electroretinography and crystal formation have also been shown with long-term betacarotene use ${ }^{46}$. More importantly, daily supplementation of beta-carotene in smokers was associated with a higher mortality rate due to ischemic heart disease and lung cancer 29,30. Since smoking also increases the risk of AMD, beta-carotene supplementation should be avoided in smokers. Currently, no biological explanation has been offered to clarify the harmful effect of beta-carotene in human.

Lutein and zeaxanthin are the only two carotenoids that exist in the human retina 34,35 . They are particularly dense in the macula in humans, where they are referred to as macular pigment ${ }^{34}$. Macular pigment is thought to be protective against retinal damage. Three casecontrolled studies showed that there was an inverse association between the macular pigment density in the human retina and the risk of AMD 47-49. In an early study investigating the effects of high dietary carotenoid intake, lutein and zeaxanthin were found to be the specific carotenoids that are most strongly associated with reduced risk of AMD 20 . This result was also supported by two other studies. The population-based Pathologies Oculaires Liees a l'Age (POLA) Study measured the plasma carotenoid levels by highperformance liquid chromatography (HPLC) in 899 subjects and correlated them with the risk of AMD 50. It was shown that high plasma levels of lutein and zeaxanthin were associated with a significant reduced risk of AMD. Similarly, a study in U.K. involving men and women aged 66 to 75 found that subjects with the lowest plasma level of zeaxanthin has a two-fold increased risk when compared with those with the highest plasma zeaxanthin, supporting the view that zeaxanthin may protect against AMD 51.

Other studies also provide evidence in the association of lutein and zeaxanthin with AMD risk. In the Blue Mountains Eye Study, Flood et al reported a possible association between baseline intake of lutein and zeaxanthin and the 5-year incidence of early AMD ${ }^{44}$. A longer, 10-year follow-up study reported that high dietary lutein and zeaxanthin intake (top tertile) was associated reduced risk of incident neovascular AMD 45. Participants with above median intakes had a reduced risk of indistinct soft or reticular drusen.

Conversely, several studies showed different results on the association of lutein and zeaxanthin. An early study in Beaver Dam (Beaver Dam Eye Study) reported no significant association between lutein and zeaxanthin and the risk of large drusen when 1,709 participants were followed up for 5 years ${ }^{23}$. In a prospective follow-up study of women in the Nurses' Health Study and men in the Health Professionals Follow-up Study, Cho et al followed 77,562 women and 40,866 men $\geq 50$ years old for up to 18 years for women and up to 12 years for men. It was reported that lutein and zeaxanthin were not strongly related to either early or neovascular AMD risk 52. The Carotenoids in Age-related Eye Disease Study (CAREDS), an ancillary study of the Women's Health Initiative, followed 1,787 female 
participants aged 50 to 79 for 4 to 7 years 53 and assessed their diet by a food frequency questionnaire. Subjects were divided according to their lutein and zeaxanthin intake, but there was no statistical difference between the amount of lutein and zeaxanthin intake and the prevalence of intermediate AMD. A later large prospective follow-up study also reported similar results 54. Two cohorts, the Nurses' Health Study and the Health Professionals Follow-up Study which included 51,564 men and 71,494 women aged $\geq 50$ years were followed up for up to 18 years. Cho et al reported that there was no association between lutein/zeaxanthin intake and the risk of self-reported early AMD. Yet, a nonsignificant and nonlinear inverse association between lutein/zeaxanthin intake and neovascular AMD risk was observed.

More recently, lutein itself has gained special interests. Two prospective randomized controlled trials have investigated the association of lutein supplementation and the incidence of AMD. The larger Veterans LAST study (Lutein Antioxidant Supplementation Trial) involved 90 subjects with atrophic AMD who were randomly divided into three groups: lutein $(10 \mathrm{mg})$ group, lutein $(10 \mathrm{mg})$ plus additional antioxidants and nutrients group, and maltodextrin placebo group ${ }^{55}$. Subjects were followed for 12 months and those who received lutein alone or lutein plus antioxidants and nutrients had improved visual acuity. Richer et al concluded that lutein alone or in combination with other nutritional supplements (including zinc, beta-carotene and vitamins $\mathrm{C}$ and $\mathrm{E}$ ) is protective and slow down the progression of AMD. On the other hand, a smaller prospective trial measured the contrast sensitivity in 25 subjects after lutein supplementation $(6 \mathrm{mg})$ with vitamins and minerals or placebo over a 6-month period 56. No statistical difference was observed between the lutein and placebo group, suggesting no significant association between lutein supplementation and AMD. However, one has to be careful about these findings. The sample sizes in both studies were fairly small and the follow-up periods were limited to 12 months or less.

More supportive evidence came from a recent study in which participants in AREDS were genotyped for the hepatic lipase (LIPC) gene ${ }^{57}$. Hepatic lipase is a protein in the highdensity lipoprotein cholesterol pathway and has been shown in a large genome-wide association study to be a novel locus for advanced AMD risk 58 . It was observed in the AREDS participants that lower dietary lutein intake was significantly associated with increased risk of advance AMD, after controlling for the LIPC genotype. This suggests that high dietary lutein intake may reduce the risk of advanced AMD, after adjusting for genetic variants.

Lutein is also a macular pigment. Due to lutein's antioxidant properties and blue-light filtering capacity 36 , it was hypothesized that macular pigment may provide protection against the development of AMD 59. The first prospective follow-up study, Muenster Aging and Retina Study (MARS), recently investigated the determinants of macular pigment optical density and its relation to AMD 60. Foveal macular pigment optical density was accessed in 369 participants including patients with different stages of AMD and healthy controls. In the 2.6-year follow-up study, it was observed that serum level of lutein, lutein supplementation in particular, was the strongest determinants of macular pigment optical density. However, the hypothetical protective effect of macular pigment in AMD could not be confirmed. On the other hand, a recent double-masked controlled study, Lutein Intervention Study Austria (LISA), investigated the association of 6-month lutein 
supplementation with macular pigment optical density and visual acuity in 126 AMD patients randomly assigned to lutein supplementation or placebo ${ }^{61}$. Weigert et al observed that lutein could significantly increase macular pigment optical density despite having no effect on mean differential light threshold or visual acuity. Interestingly, a significant correlation was found between the lutein-induced increase in macular pigment optical density and the change in mean differential light threshold and visual acuity. This finding suggests that patients who experience a pronounced increase in macular pigment optical density after lutein supplementation may benefit in terms of visual function.

As lutein and zeaxanthin were not ready for manufacturing as a research formula, neither of them was included in the AREDS formula 28. The US Food and Drug Administration (FDA) has conducted an evidence-based review to evaluate the role of lutein and zeaxanthin in reducing the risk of AMD 62. After reviewing a number of intervention and observational studies, the FDA denied a health claim about the intake of lutein or zeaxanthin (or both) and the risk of AMD in 2006. However, in view of the conflicting findings, the National Eye Institute (Bethesda, Maryland, USA) launched the Age-Related Eye Disease Study 2 (AREDS2) in 2006, hoping to resolve the link between carotenoids (lutein and zeaxanthin) intake and AMD protection ${ }^{32,33}$. The AREDS2, a large, multi-centered, randomized trial, is currently underway to address the effects of high dose lutein and zeaxanthin supplementation and/or omega-3 fatty acids on the progression of AMD. Beta-carotene, which increases the risk of lung cancer in smokers 29,30, is removed from the AREDS2 formula. Another on-going, similar randomized controlled trial is the Carotenoids in AgeRelated Maculopathy (CARMA) Study ${ }^{63}$. In this study, 433 participants with either early AMD features or any level of AMD in one eye and advanced AMD in the fellow eye were recruited. Either lutein and zeaxanthin, in combination with antioxidants (including vitamin C, vitamin E, zinc, and copper) or placebo was given. Again, beta-carotene was excluded in the preparation due to the increased risk of lung cancer in smokers 29,30.

Although the beneficial effects have not been proven, lutein and zeaxanthin are included in daily supplements and food additives and can be obtained over the counter. Moreover, the addition of crystalline lutein into food and beverage products is considered GRAS (generally recognized as safe) and is approved by the FDA 64 . Lutein toxicity studies in animals using high doses of purified crystalline lutein revealed no unfavorable events ${ }^{64}$ and no adverse events are reported for lutein and zeaxanthin at doses up to $40 \mathrm{mg} /$ day in human for 2 months ${ }^{65}$. The risk profile of lutein was also recently reviewed in 2006 by the Council for Responsible Nutrition (CRN) in Washington, D.C. It was concluded that apart from the reversible skin discoloration, no other adverse effects were observed ${ }^{66}$. The CRN suggested an upper level of intake for lutein up to $20 \mathrm{mg} /$ day. Currently, the average daily intake for lutein and zeaxanthin is $2.0-2.3 \mathrm{mg} /$ day for men and $1.7-2.0 \mathrm{mg} /$ day for women in United States (Food and Nutrition Board, 2001).

In view of their potential benefits as well as minimal side effects, lutein and zeaxanthin may be recommended for those who are keen and at risk of AMD 27.

\subsection{Vitamin C (L-ascorbic acid)}

Vitamin $C$ is a water-soluble nutrient that is synthesized in almost all animals and plants. It is well known for its potent antioxidant activities 67,68 . It also acts as an important co-factor 
in mammals as in the synthesis of collagen; therefore vitamin $C$ is used in the treatment and prevention of scurvy. In ophthalmology, there has not been any randomized controlled trial in assessing the efficacy of vitamin $C$ as a single supplement in AMD. Yet, in other studies combining vitamin $C$ with other supplements, data on the protective effects of vitamin $C$ has been mixed. Vitamin $C$ is shown to be beneficial in the AREDS study ${ }^{19}$. In two large prospective studies of 135 men and 329 women with up to 18 years of follow-up 52, it was found that higher fruit intake was related to a reduced risk of neovascular age-related maculopathy but none of the vitamins (including vitamin C) or carotenoids examined was clearly related to the disease. In a population-based cohort study involving 1,586 middleaged and older adults, the researchers found no significant associations between the risk of large drusen and intake of vitamin $C{ }^{23}$. Another population-based cohort study even suggested that an increasing baseline vitamin $C$ intake from diet and supplements was associated with an increased risk of incident early age-related maculopathy when compared with the lowest quintile 44

\subsection{Vitamin E ( $\alpha$-tocopherol)}

Vitamin $\mathrm{E}$ is a collective term for a group of natural lipid-soluble compounds containing the tocopherols $(\alpha-, \beta-, \gamma$ - and $\delta$-) and tocotrienols $(\alpha-, \beta-, \gamma-$ and $\delta$-) with antioxidant properties. Among them, $\alpha$-tocopherol is the only form to meet human requirements. In the eye, $\alpha$ tocopherol can be found in the retina, RPE and choroid ${ }^{69}$. Its concentration in the retina increases after oral supplements ${ }^{70}$.

As an antioxidant and a nutritional factor, vitamin $\mathrm{E}$ has been explored in its association with prevention of AMD. Again, data for vitamin E have been mixed. Some studies reported that higher intake are associated with lower risks of AMD or signs $23,42,71$ whereas some concluded no associations $45,52,72,73$.

In particular, three large randomized controlled trials have assessed vitamin $\mathrm{E}$ in the incidence of AMD. The Alpha-Tocopherol and Beta-Carotene (ATBC) Study involved over 29,000 smoking males aged 50 to 69 years who were randomly assigned to alphatocopherol (50 mg/day), beta-carotene $\left(20 \mathrm{mg} /\right.$ day), both of these, or placebo ${ }^{43}$. Of these, an end-of-trial ophthalmological examination was performed in a random sample of 941 participants aged 65 years or more. No beneficial effect of long-term supplementation with alpha-tocopherol on the occurrence of AMD was detected among smoking males. In the Vitamin E Cataract and Age-related Maculopathy Trial (VECAT), 1,193 healthy volunteers aged between 55 and 80 years were randomly given either vitamin $\mathrm{E}(500 \mathrm{IU}=$ $335 \mathrm{mg}$ ) or placebo daily for 4 years ${ }^{74}$. In the study, the incidence of early AMD in those receiving vitamin $\mathrm{E}(8.6 \%)$ was similar to those on placebo $(8.1 \%)$ whereas for late disease the incidence was $0.8 \%$ versus $0.6 \%$. Again, daily vitamin E supplement does not prevent the development or progression of early or later stages of AMD. In the Women's Health Study (WHS) 75, a large scale randomized trial of women, 39,876 healthy female health professionals were randomly assigned to receive with natural source vitamin E (600IU) or placebo on alternate days. There were 117 AMD cases in the vitamin E group versus 128 cases in the placebo group after 10 years of treatment and follow-up. Similar to other studies, no large beneficial or harmful effect on risk of AMD was observed in long term vitamin E supplementation. 
More importantly, a negative association between vitamin E and AMD was recently reported. In the Blue Mountains Eye Study involving an Australian population-based cohort, Tan et al reported that high vitamin E intake was associated with increased risk of late AMD, suggesting a harmful effect of dietary vitamin E on risk of AMD 45 . However, one has to be cautious about these results. There was a moderate loss of participants in this particular study, while the levels of vitamin E intake between participants followed up and not followed up were significantly different. The authors mentioned that this might affect the interpretation of the observed results.

\subsection{Zinc}

Zinc is an essential trace element for almost all organisms including plants, animals and microorganisms. It has a multitude of biological roles, playing a fundamental role in cellular metabolism. For example, it plays a structural role in a large number of transcription factors containing zinc fingers and similar structural motifs. Most importantly, it was first shown to be required for the catalytic activity of carbonic anhydrase ${ }^{76}$. Later studies showed that zinc has a catalytic or structural role in at least 300 zinc metalloenzymes 77-79, influencing many metabolic reactions. In fact, approximately $10 \%$ of the human genome encodes for proteins that can bind zinc 80 .

In the human body, there are about 2-3 $\mathrm{g}$ of zinc, making it the second most abundant trace element 79,81 . In ocular tissues, the concentration of zinc is unusually high when compared with other tissues ${ }^{82}$. In the eye zinc is most abundant in the retina and choroid, followed by ciliary body, iris, optic nerve, sclera, cornea, and lens ${ }^{83}$. A number of functions of zinc in the retina have been suggested, including modulation of retinal synaptic transmission, modification of photoreceptor plasma membrane, involvement in retinal vitamin A metabolism, regulation of light-rhodopsin reaction within the photoreceptor, and antioxidant activity 84,85 .

There are subtle ocular manifestations associated with zinc deficiency. In a prospective, randomized, double-masked, placebo-controlled investigation of the effects of oral zinc administration on the visual acuity outcome in 151 subjects with drusen or macular degeneration, the treatment group had significantly less visual loss than the placebo group 24. As elderly patients are found to be at higher risk of zinc deficiency 86 , this may suggest an increased risk of vision loss from AMD in elderly patients.

For the past three decades, there have been considerable interest and controversy related to zinc supplementation in AMD patients. To date, results on zinc supplementation and AMD have been mixed. As described above, Newsome et al reported significant reduction in visual loss in AMD patients when supplemented with oral zinc ${ }^{24}$. Moreover, MaresPerlman et al reported a weak protective effect of dietary zinc on the development of some forms of early AMD 71 . In the large double-masked clinical trial, The Age-Related Eye Disease Study (AREDS), involving 11 centers, participants taking zinc alone demonstrated an odds reduction of 0.75 for the development of advanced AMD. Zinc significantly reduced the odds of developing advanced AMD in the higher-risk group. A population-based cohort study reported that high dietary zinc intake was associated with a lower risk of incident AMD 42. In the Beaver Dam Eye Study, it was observed that there is a significant inverse association between zinc and the incidence of pigmentary abnormalities, but there was no 
relationship between zinc intake and incidence of early AMD ${ }^{23}$. In fact, an early study by the Eye Diseases Case-Control Study Group reported no association between serum zinc levels and risk of neovascular AMD 40. In a 2-year, double-masked, randomized, placebocontrolled study, Stur et al reported that oral zinc substitution has no short-term effect in patients who have an exudative form of AMD in one eye ${ }^{87}$. Unfortunately, this study was prematurely terminated because of no beneficial effects found in first 40 patients at 24 months. In addition, two large prospective studies involving 66,572 women and 37,636 men do not support a lowered AMD risk associated with higher zinc intake 88 . The Blue Mountains Eye Study Group reported no significant association between baseline zinc intake from diet or supplements and the 5-year incidence of early Age-related maculopathy 44 .

A systematic review and meta-analysis involving four prospective cohort studies $23,42,44,88$ reported that a pooled odds ratio of zinc for early AMD was 0.91 (95\% CI 0.74 to 1.11). Another meta-analysis reported that zinc supplementation can slow down AMD progression (adjusted odds ratio $=0.77,95 \%$ CI 0.62 to 0.96 ) ${ }^{89}$.

Although the evidence is conflicting, recent studies support a protective role of zinc in AMD progression. The AREDS study indicated that the beneficial effect of zinc supplementation was of a similar order to that of vitamin supplementation. Despite the 5-year findings by The Blue Mountains Eye Study Group 44, later studies by the same group published the 10year data in which individuals with total zinc intake in the highest decile are less likely to develop early or any AMD 45.

Zinc intake and the genetic risk of AMD has also been assessed. In the AREDS population, the single nucleotide polymorphism in the CFH (Y402H, rs1061170) and LOC387715/ARMS2 (A69S, rs10490924) genes of 876 participants who were considered at high risk was genotyped ${ }^{90}$. The findings suggest that there is an interaction between $\mathrm{CFH}$ genotype and treatment with antioxidant plus zinc when compared with placebo. Moreover, a recent study involving 2,167 individuals from the population-based Rotterdam Study at genetic risk of AMD assessed their dietary intake at baseline using a semi-quantitative food frequency questionnaire and determined the genetic variants using TaqMan assay ${ }^{91}$. In this nested case-control study, it was observed that there is a significant possibility of biological interaction between CFH Y402H and zinc as well as between LOC387715 A69S and zinc ( $\mathrm{p}<$ 0.05). Moreover, individuals with homozygous $\mathrm{CFH} \mathrm{Y402H}$ with dietary intake of zinc in the highest tertile reduced their hazard ratio of early AMD from 2.25 to 1.27.

Again, one has to be cautious about the risks of high dose supplementary intake of zinc. In the AREDS study, more people in the zinc group reported difficulty in swallowing the tablets $(17.8 \%$ vs. $15.3 \%, \mathrm{p}<0.04){ }^{19}$. Circulatory adverse experiences were also more frequently reported in individuals receiving zinc. Hospitalizations due to genitourinary problems as well as mild or moderate symptoms are also more frequent in these participants. In fact, it was found that there is a significant increase in hospital admissions for urinary complications in patients with high zinc supplementation $(11.1 \%$ vs $7.6 \%, \mathrm{p}=$ 0.0003 ) ${ }^{92}$. The risk was greatest in male patients (RR 1.26, 95\% CI 1.07-1.50, $p=0.008$ ). Significant increase in urinary tract infections was also found $(p=0.004)$, especially in females. Another problem was gastrointestinal symptoms. Of 286 participants, 5/146 zinc- 
treated participants withdrew from the studies due to gastrointestinal symptoms when compared with 2/140 in the placebo group 24,87 .

\subsection{Omega-3 Long chain polyunsaturated fatty acids}

The retina contains abundant fatty acids, about $30 \%$ of which are polyunsaturated fatty acids ${ }^{93}$. Polyunsaturated fatty acids are classified into 2 groups: $\omega-3$ and $\omega-6$ depending on the position of the first double bond from the methyl end of the molecule. Docosahexaenoic acid (DHA), an omega-3 fatty acid, is highly enriched in the retina, particularly in the disc membrane of photoreceptor outer segments ${ }^{94}$. DHA is the major polyunsaturated fatty acid in cerebral gray matter as well. Yet, the specific role of DHA in the eye is not clear. DHA has been shown to be important for photoreceptor survival ${ }^{95-98}$. DHA may have a role in modulating $G$ protein-coupled signaling pathways that are involved in visual transduction 99. DHA may also affect rhodopsin function during photoreception by influencing the membrane's biophysical properties 100,101. In rhesus monkeys, dietary depletion of alphalinolenic acid, a dietary precursor of DHA, resulted in undetectable plasma DHA level and more importantly, abnormal retinogram and visual impairment 102,103. Nonetheless, DHA supplementation is effective in improving retinal function in a patient with autosomal dominant Stargardt-like retinal dystrophy ${ }^{104}$. The importance of DHA in retinal function may suggest a possible beneficial role of DHA in retinal disease such as AMD.

Another omega-3 fatty acid, eicosapentaenoic acid (EPA), is the precursor of eicosanoids in the body. It can act as a competitive inhibitor of arachidonic acid conversion to proinflammatory eicosanoids prostaglandin $\mathrm{E}(2)$ and leukotriene $\mathrm{B}(4){ }^{105}$. As inflammation plays a role in the pathogenesis of AMD, EPA may be one of the protective factors in AMD.

Supplementation of omega-3 fatty acids, DHA and EPA in particular, has received much interest in association with lowering the risk of AMD. Although DHA can be synthesized from alpha-linolenic acid in the body, the process is ineffective. DHA and EPA can readily be obtained from marine fish oils in the diet. Based on their roles in retinal function and inflammation, dietary modification and supplementation of omega-3 fatty acids have become attractive alternatives in lowering the risk of AMD.

Many studies have provided evidence for a protective role of omega-3 fatty acids supplementation in AMD risk 91,106-117. The first study evaluating the relationship between dietary fat and AMD was published by Mares-Perlman et al 106 . They reported that high intake of saturated fat and cholesterol was associated with increased risk for early AMD. Later, a prospective follow-up study of participants in the Nurses' Health Study and the Health Professionals Follow-up Study showed that total fat intake was positively associated with increased risk of AMD 108. Yet, a cross-sectional study involving participants in the Third National Health and Nutrition Examination Survey found no association between dietary fat and AMD risk. However, this study assessed only one eye per patient, thereby may have decreased the observed AMD prevalence.

There are further investigations into the association of omega-3 fatty acids with AMD risk. As dietary omega-3 fatty acids are obtained from marine fish oils, fish intake was also investigated. Earlier study on fish intake was performed in the Blue Mountain Eye Study population. In this cross-sectional, population based study, Smith et al showed that a higher 
fish consumption was associated with decreased odds of late AMD 107. After 5 years of follow-up Chua et al reported that fish consumption at least once a week was protective against early AMD, whereas fish consumption at least 3 times per week could reduce the incidence of late AMD ${ }^{110}$. After 10 years of follow up in the same cohort, Tan et al suggested that a regular weekly serving of fish was associated with a reduced risk of early AMD 116 . Interestingly, it was also noted that fish consumption of more than one serving per week did not have a significant protective effect in reducing AMD risk in this cohort, suggesting a threshold effect. These findings are supported by other studies as well. Seddon et al in a multicenter eye disease case-control study reported that higher intake of omega-3 fatty acids and fish was associated with a lower risk for AMD among individuals with low linoleic acid intake ${ }^{109}$. More evidence on the protective role of omega-3 fatty acid came from a recent US Twin Study of Age-Related Macular Degeneration. This study investigated the association between dietary fat intake and fish consumption and risks of AMD in 681 twins 111 and found that both omega- 3 and fish intake reduced the risk of AMD.

Oily fish rich in omega-3 fatty acids are also found to be beneficial in two European studies. The population-based POLANUT study from Southern France found that fatty fish intake was protective against AMD when comparing more than once a month and less than once a month and after multvariate adjustment ${ }^{112}$. Interestingly, total and white fish intake has no significant association with AMD risk. Another population-based study, EUREYE, showed that oily fish intake (at least once per week versus less than once per week) was associated with significant reduction of risk for neovascular AMD 114. Similar findings were also observed for either DHA or EPA intake.

Among the AREDS participants, a prospective cohort of individuals with neovascular AMD and central geographic atrophy was also analyzed for the relationship of omega-3 fatty acids and AMD. It was observed that dietary total omega-3 fatty acids or DHA intake was inversely associated with neovascular AMD 113. Similar findings were also observed with fish consumption. Further studies showed that dietary omega-3 fatty acids intake is associated with a decreased risk of progression from bilateral drusen to central geographic atrophy 115 .

In addition, the association between omega- 3 fatty acids and genetic risk of AMD is investigated. In the Blue Mountains Study group, 1881 participants were genotyped for complement factor $\mathrm{H}(\mathrm{CFH})$ genetic variants 117. Wang et al reported that AMD risk increased with each additional C allele. Also, weekly compared with less than weekly consumption of fish was associated with reduced late AMD risk in participants with the CC genotype but not the CT or TT genotypes. This study provided evidence that weekly consumption of fish is protective on the development of late AMD, but not early AMD, among individuals with genetic susceptibility to AMD due to the $\mathrm{Y} 402 \mathrm{H}$ variant. On the other hand, the dietary intake of 2167 individuals was assessed at baseline in a recent population-based Rotterdam study ${ }^{91}$. Ho et al reported a possible interaction between EPA/DHA and either CFH Y402H or LOC387715 A69S. The authors also suggested that high dietary intake of omega-3 fatty acids may reduce the risk of early AMD in those who are at high genetic risk.

Taken together, much data suggests that dietary omega-3 fatty acids intake and fish consumption are protective against AMD. Results from a recent meta-analysis also 
supported the protective role of omega- 3 fatty acids supplementation ${ }^{118}$. It was reported that dietary intake of omega-3 fatty acids was associated with reduced risk of late AMD while fish consumption (at least twice a week) was associated with reduced risk of both early and late AMD. However, the authors also cautioned that due to insufficient evidence, few prospective studies and no randomized clinical trials, recommendation for a routine omega-3 fatty acids supplementation and fish consumption for AMD prevention is not supported. A similar conclusion was also reached in another systematic review 119 . Hopefully, more definite answers on the protective role of omega-3 fatty acids will be provided by the ongoing AREDS2 randomized, multi-center trial.

\subsection{B vitamins}

B vitamins are a group of water-soluble compounds that are important in cell metabolism. The members of interest in AMD studies are folic acid, vitamin $B_{6}$ (pyridoxine) and vitamin $\mathrm{B}_{12}$ (cyanocobalamin) because of their ability to reduce homocysteine levels in intervention studies ${ }^{120}$. Homocysteine is an amino acid formed during the metabolism of methionine. It can either be recycled back into methionine or converted into cysteine with the help of Bvitamins.

Serum level of homocysteine has been implicated in increasing the risk of AMD. Recent cross-sectional ${ }^{121-123}$ and case-control studies ${ }^{124-128}$ showed that there may be a direct association between homocysteine level in the blood and AMD. Hyperhomocysteinemia (plasma homocysteine $>15 \mu \mathrm{mol} / \mathrm{L}$ ) can also induce vascular endothelial dysfunction 129-131. It was therefore proposed that lowering blood homocysteine levels with folic acid, vitamin $\mathrm{B}_{6}$ and vitamin $\mathrm{B}_{12}$ supplementation may help to reduce the risk of AMD.

In the Women's Antioxidant and Folic Acid Cardiovascular Study (WAFACS), 5,442 female health professionals participated in this randomized, double-masked, placebo controlled trial ${ }^{132}$. Christen et al reported that daily supplementation with folic acid $/ \mathrm{B}_{6} / \mathrm{B}_{12}$ reduce the risk of AMD in this large cohort of females after an average of 7.3 years of treatment and follow-up. Yet, disease report in this study was done by self-report questionnaires or medical records while no ophthalmic examinations were performed. More evidence and further research in other groups are needed despite the interesting association between folic acid/ $\mathrm{B}_{6} / \mathrm{B}_{12}$ supplementation and AMD prevention.

\subsection{Berry extracts}

Diets rich in fruits, nuts, and vegetables have long been considered to be an excellent source of antioxidants. There has been growing interest on berry extracts due to their high antioxidant properties. Among the berries, blueberries have been of specific interest because of their high antioxidant capacity (in some cases as high as 40-50 $\mu$ mol Trolox equivalents/g) ${ }^{133}$. Indeed, of all the fresh fruits and vegetables tested to date, data indicate that blueberries have the highest antioxidant capacity, as estimated using the average oxygen radical absorbance capacity (ORAC) values 133-135. Polyphenols in blueberries, specifically the anthocyanins that give the fruit its blue color, are the major contributors to antioxidant activity 133 . 
Anthocyanin is a water-soluble pigment present in all plants and is richly concentrated in berries. It is a powerful antioxidant in vitro ${ }^{136}$. It can absorb blue-green light and protects the cells from light stress in plant studies ${ }^{137}$. In laboratory studies, anthocyanin may protect the eyes from degenerative diseases such as AMD 138-140. Yet, the evidence for the potential health effects of anthocyanin is mostly laboratory-based ${ }^{141}$.

Another berry that recently received lots of interest is the fruit of Lycium barbaurm, also called wolfberry or Gouqizi, a commonly used herb in Chinese Traditional Medicine. It is also taken as food in Asian countries. It is well known for improving eye sight. Increasing lines of evidence showed that the polysaccharides in Lycium barbaurm can exhibit anti-aging 142 and anti-oxidative effects ${ }^{143}$. Other properties such as anti-tumor effects, cytoprotection, neuromodulation, and immune modulations have also been suggested 142,144. Unfortunately, most evidence for its beneficial effects is limited to the laboratory level.

At this moment, there are no legal requirements for quality control in the preparation of these extracts. It is not obligatory to disclose the content and the production method. Moreover, the dosage and frequency are unclear while potential toxicity and long-term side effects remain to be investigated. A lot of investigation is needed before the potential of berry extracts in prevention of AMD can be hinted. Currently, berry extracts should not be recommended 27 .

\section{Future directions}

Observational studies have shown beneficial effects from dietary supplementation of lutein and zeaxanthin as well as omega-3 fatty acids in the development of AMD. They are currently tested in AREDS2, the multi-centered randomized clinical trial launched by the National Eye Institute in 2006. The association of oral formulations containing lutein and zeaxanthin, and/or DHA and EPA, with the progression of AMD is being assessed. In AREDS2 participants will be followed for 5 years. Hopefully, data will be available by the end of 2012. Similarly, the ongoing CARMA study will also provide invaluable data on the protective effects of lutein and zeaxanthin in combination with antioxidants (vitamin C, vitamin E and zinc) with the exclusion of DHA and EPA.

\section{Conclusions}

To date a large body of evidence has supported a protective role of nutritional supplements in the development and progression of AMD. In particular, strongest evidence is present for the protective effect of lutein, zeaxanthin, DHA, and EPA. On the other hand, beta-carotene and vitamin $\mathrm{E}$ may have detrimental effects. While awaiting a further proof of the effects of lutein, zeaxanthin, DHA, and EPA, the AREDS formulation remains the best recommendation so far, although not without risk and maybe only for high-risk individuals. One concern for the AREDS formulation is the higher risk of lung cancer in smokers with daily beta-carotene supplementation. Therefore, in offering nutritional supplements to patients, physicians should consider on a case-by-case basis and fully explain the potential side effects from a long-term regular intake. It is also important to remind the patients that even with the AREDS formulation, AMD can still occur. It is equally important to teach the patients self-monitoring methods such as usage of the Amsler grid. Regular fundal examinations by ophthalmologists should also be strongly encouraged. 


\section{Reference}

[1] Friedman DS, O'Colmain BJ, Munoz B, Tomany SC, McCarty C, de Jong PT, Nemesure B, Mitchell P, and Kempen J (2004) Prevalence of age-related macular degeneration in the United States. Archives of ophthalmology 122:564-72.

[2] Finkel T and Holbrook NJ (2000) Oxidants, oxidative stress and the biology of ageing. Nature 408:239-47.

[3] Hayflick L and Moorhead PS (1961) The serial cultivation of human diploid cell strains. Experimental cell research 25:585-621.

[4] Yuan H, Kaneko T, and Matsuo M (1995) Relevance of oxidative stress to the limited replicative capacity of cultured human diploid cells: the limit of cumulative population doublings increases under low concentrations of oxygen and decreases in response to aminotriazole. Mechanisms of ageing and development 81:159-68.

[5] Adelfalk C, Lorenz M, Serra V, von Zglinicki T, Hirsch-Kauffmann M, and Schweiger M (2001) Accelerated telomere shortening in Fanconi anemia fibroblasts--a longitudinal study. FEBS letters 506:22-6.

[6] Rubio MA, Davalos AR, and Campisi J (2004) Telomere length mediates the effects of telomerase on the cellular response to genotoxic stress. Experimental cell research 298:17-27.

[7] Golden TR and Melov S (2001) Mitochondrial DNA mutations, oxidative stress, and aging. Mechanisms of ageing and development 122:1577-89.

[8] Ballinger SW, Van Houten B, Jin GF, Conklin CA, and Godley BF (1999) Hydrogen peroxide causes significant mitochondrial DNA damage in human RPE cells. Experimental eye research 68:765-72.

[9] Catala A (2006) An overview of lipid peroxidation with emphasis in outer segments of photoreceptors and the chemiluminescence assay. The international journal of biochemistry $\mathcal{E}$ cell biology 38:1482-95.

[10] Sickel W (1972) Electrical and metabolic manifestations of receptor and higher-order neuron activity in vertebrate retina. Advances in experimental medicine and biology 24:101-18.

[11] Castorina C, Campisi A, Di Giacomo C, Sorrenti V, Russo A, and Vanella A (1992) Lipid peroxidation and antioxidant enzymatic systems in rat retina as a function of age. Neurochem Res 17:599-604.

[12] Kennedy CJ, Rakoczy PE, and Constable IJ (1995) Lipofuscin of the retinal pigment epithelium: a review. Eye 9 ( $\mathrm{Pt}$ 6):763-71.

[13] Feeney-Burns L, Hilderbrand ES, and Eldridge S (1984) Aging human RPE: morphometric analysis of macular, equatorial, and peripheral cells. Invest Ophthalmol Vis Sci 25:195-200.

[14] Ng KP, Gugiu B, Renganathan K, Davies MW, Gu X, Crabb JS, Kim SR, Rozanowska MB, Bonilha VL, Rayborn ME, Salomon RG, Sparrow JR, Boulton ME, Hollyfield JG, and Crabb JW (2008) Retinal pigment epithelium lipofuscin proteomics. Molecular \& cellular proteomics : MCP 7:1397-405.

[15] Shamsi FA and Boulton M (2001) Inhibition of RPE lysosomal and antioxidant activity by the age pigment lipofuscin. Invest Ophthalmol Vis Sci 42:3041-6.

[16] Zareba M, Szewczyk G, Sarna T, Hong L, Simon JD, Henry MM, and Burke JM (2006) Effects of photodegradation on the physical and antioxidant properties of 
melanosomes isolated from retinal pigment epithelium. Photochemistry and photobiology 82:1024-9.

[17] Coleman $\mathrm{H}$ and Chew E (2007) Nutritional supplementation in age-related macular degeneration. Curr Opin Ophthalmol 18:220-3.

[18] Chiu CJ and Taylor A (2007) Nutritional antioxidants and age-related cataract and maculopathy. Exp Eye Res 84:229-45.

[19] Group A-REDSR (2001) A randomized, placebo-controlled, clinical trial of high-dose supplementation with vitamins $\mathrm{C}$ and $\mathrm{E}$, beta carotene, and zinc for age-related macular degeneration and vision loss: AREDS report no. 8. Arch Ophthalmol 119:1417-36.

[20] Seddon JM, Ajani UA, Sperduto RD, Hiller R, Blair N, Burton TC, Farber MD, Gragoudas ES, Haller J, Miller DT, and et al. (1994) Dietary carotenoids, vitamins A, C, and E, and advanced age-related macular degeneration. Eye Disease CaseControl Study Group. JAMA 272:1413-20.

[21] Snellen EL, Verbeek AL, Van Den Hoogen GW, Cruysberg JR, and Hoyng CB (2002) Neovascular age-related macular degeneration and its relationship to antioxidant intake. Acta Ophthalmol Scand 80:368-71.

[22] Goldberg J, Flowerdew G, Smith E, Brody JA, and Tso MO (1988) Factors associated with age-related macular degeneration. An analysis of data from the first National Health and Nutrition Examination Survey. Am J Epidemiol 128:700-10.

[23] VandenLangenberg GM, Mares-Perlman JA, Klein R, Klein BE, Brady WE, and Palta M (1998) Associations between antioxidant and zinc intake and the 5-year incidence of early age-related maculopathy in the Beaver Dam Eye Study. Am J Epidemiol 148:204-14.

[24] Newsome DA, Swartz M, Leone NC, Elston RC, and Miller E (1988) Oral zinc in macular degeneration. Arch Ophthalmol 106:192-8.

[25] Moriarty-Craige SE, Ha KN, Sternberg P, Jr., Lynn M, Bressler S, Gensler G, and Jones DP (2007) Effects of long-term zinc supplementation on plasma thiol metabolites and redox status in patients with age-related macular degeneration. Am J Ophthalmol 143:206-211.

[26] website IoMotNA. Dietary Reference Intakes. [cited 2007 Dec 15]; Available from: http://www.iom.edu/CMS/3788/4574.aspx.

[27] Wong IY, Koo SC, and Chan CW (2011) Prevention of age-related macular degeneration. International ophthalmology 31:73-82.

[28] Klein R, Peto T, Bird A, and Vannewkirk MR (2004) The epidemiology of age-related macular degeneration. Am J Ophthalmol 137:486-95.

[29] The Alpha-Tocopherol BCCPSG (1994) The effect of vitamin E and beta carotene on the incidence of lung cancer and other cancers in male smokers. The AlphaTocopherol, Beta Carotene Cancer Prevention Study Group. N Engl J Med 330:102935.

[30] Omenn GS, Goodman GE, Thornquist MD, Balmes J, Cullen MR, Glass A, Keogh JP, Meyskens FL, Valanis B, Williams JH, Barnhart S, and Hammar S (1996) Effects of a combination of beta carotene and vitamin A on lung cancer and cardiovascular disease. N Engl J Med 334:1150-5. 
[31] Evans JR (2006) Antioxidant vitamin and mineral supplements for slowing the progression of age-related macular degeneration. Cochrane Database Syst Rev:CD000254.

[32] website A. Age-Related Eye Disease Study 2. [cited 2011 Sep 7]; Available from: http://clinicaltrials.gov/ct2/show/NCT00345176?term=AREDS2\&rank=1.

[33] AREDS2. Age-Related Eye Disease Study 2. Manual of Procedures. 2009 [cited 2011 Sep 7]; Available from:

https://web.emmes.com/study/areds2/resources/areds2_mop.pdf.

[34] Bone RA, Landrum JT, and Tarsis SL (1985) Preliminary identification of the human macular pigment. Vision Res 25:1531-5.

[35] Parker RS (1989) Carotenoids in human blood and tissues. J Nutr 119:101-4.

[36] Diplock AT, Charleux JL, Crozier-Willi G, Kok FJ, Rice-Evans C, Roberfroid M, Stahl W, and Vina-Ribes J (1998) Functional food science and defence against reactive oxidative species. Br J Nutr 80 Suppl 1:S77-112.

[37] Gruszecki WI, Sujak A, Gabrielska J, Grudzinski W, Borc R, and Mazurek P (1999) Lutein and zeaxanthin as protectors of lipid membranes against oxidative damage: The structural aspects. Arch Biochem Biophys 371:301-307.

[38] Li SY and Lo AC (2010) Lutein Protects RGC-5 Cells Against Hypoxia and Oxidative Stress. Int J Mol Sci 11:2109-17.

[39] Li SY, Fu ZJ, Ma H, Jang WC, So KF, Wong D, and Lo AC (2009) Effect of lutein on retinal neurons and oxidative stress in a model of acute retinal ischemia/reperfusion. Invest Ophthalmol Vis Sci 50:836-43.

[40] Group TEDC-CS (1992) Risk factors for neovascular age-related macular degeneration. The Eye Disease Case-Control Study Group. Arch Ophthalmol 110:1701-8.

[41] Malinow MR, Feeney-Burns L, Peterson LH, Klein ML, and Neuringer M (1980) Dietrelated macular anomalies in monkeys. Invest Ophthalmol Vis Sci 19:857-63.

[42] van Leeuwen R, Boekhoorn S, Vingerling JR, Witteman JC, Klaver CC, Hofman A, and de Jong PT (2005) Dietary intake of antioxidants and risk of age-related macular degeneration. JAMA 294:3101-7.

[43] Teikari JM, Laatikainen L, Virtamo J, Haukka J, Rautalahti M, Liesto K, Albanes D, Taylor P, and Heinonen OP (1998) Six-year supplementation with alpha-tocopherol and beta-carotene and age-related maculopathy. Acta Ophthalmol Scand 76:224-9.

[44] Flood V, Smith W, Wang JJ, Manzi F, Webb K, and Mitchell P (2002) Dietary antioxidant intake and incidence of early age-related maculopathy: the Blue Mountains Eye Study. Ophthalmology 109:2272-8.

[45] Tan JS, Wang JJ, Flood V, Rochtchina E, Smith W, and Mitchell P (2008) Dietary antioxidants and the long-term incidence of age-related macular degeneration: the Blue Mountains Eye Study. Ophthalmology 115:334-41.

[46] Yoser SL and Heckenlively JR (1989) The appearance of retinal crystals in retinitis pigmentosa patients using beta-carotene. Invest Ophthalmol Vis Sci 30 Suppl:305.

[47] Beatty S, Murray IJ, Henson DB, Carden D, Koh H, and Boulton ME (2001) Macular pigment and risk for age-related macular degeneration in subjects from a Northern European population. Invest Ophthalmol Vis Sci 42:439-46.

[48] Bone RA, Landrum JT, Mayne ST, Gomez CM, Tibor SE, and Twaroska EE (2001) Macular pigment in donor eyes with and without AMD: a case-control study. Invest Ophthalmol Vis Sci 42:235-40. 
[49] Bernstein PS, Zhao DY, Wintch SW, Ermakov IV, McClane RW, and Gellermann W (2002) Resonance Raman measurement of macular carotenoids in normal subjects and in age-related macular degeneration patients. Ophthalmology 109:1780-7.

[50] Delcourt C, Carriere I, Delage M, Barberger-Gateau P, and Schalch W (2006) Plasma lutein and zeaxanthin and other carotenoids as modifiable risk factors for agerelated maculopathy and cataract: the POLA Study. Invest Ophthalmol Vis Sci 47:2329-35.

[51] Gale CR, Hall NF, Phillips DI, and Martyn CN (2003) Lutein and zeaxanthin status and risk of age-related macular degeneration. Invest Ophthalmol Vis Sci 44:2461-5.

[52] Cho E, Seddon JM, Rosner B, Willett WC, and Hankinson SE (2004) Prospective study of intake of fruits, vegetables, vitamins, and carotenoids and risk of age-related maculopathy. Arch Ophthalmol 122:883-92.

[53] Moeller SM, Parekh N, Tinker L, Ritenbaugh C, Blodi B, Wallace RB, and Mares JA (2006) Associations between intermediate age-related macular degeneration and lutein and zeaxanthin in the Carotenoids in Age-related Eye Disease Study (CAREDS): ancillary study of the Women's Health Initiative. Arch Ophthalmol 124:1151-62.

[54] Cho E, Hankinson SE, Rosner B, Willett WC, and Colditz GA (2008) Prospective study of lutein/zeaxanthin intake and risk of age-related macular degeneration. Am J Clin Nutr 87:1837-43.

[55] Richer S, Stiles W, Statkute L, Pulido J, Frankowski J, Rudy D, Pei K, Tsipursky M, and Nyland J (2004) Double-masked, placebo-controlled, randomized trial of lutein and antioxidant supplementation in the intervention of atrophic age-related macular degeneration: the Veterans LAST study (Lutein Antioxidant Supplementation Trial). Optometry 75:216-30.

[56] Bartlett HE and Eperjesi F (2007) Effect of lutein and antioxidant dietary supplementation on contrast sensitivity in age-related macular disease: a randomized controlled trial. Eur J Clin Nutr 61:1121-7.

[57] Seddon JM, Reynolds R, and Rosner B (2010) Associations of smoking, body mass index, dietary lutein, and the LIPC gene variant rs10468017 with advanced agerelated macular degeneration. Mol Vis 16:2412-24.

[58] Neale BM, Fagerness J, Reynolds R, Sobrin L, Parker M, Raychaudhuri S, Tan PL, Oh EC, Merriam JE, Souied E, Bernstein PS, Li B, Frederick JM, Zhang K, Brantley MA, Jr., Lee AY, Zack DJ, Campochiaro B, Campochiaro P, Ripke S, Smith RT, Barile GR, Katsanis N, Allikmets R, Daly MJ, and Seddon JM (2010) Genome-wide association study of advanced age-related macular degeneration identifies a role of the hepatic lipase gene (LIPC). Proc Natl Acad Sci U S A 107:7395-400.

[59] Loane E, Kelliher C, Beatty S, and Nolan JM (2008) The rationale and evidence base for a protective role of macular pigment in age-related maculopathy. Br J Ophthalmol 92:1163-8.

[60] Dietzel M, Zeimer M, Heimes B, Claes B, Pauleikhoff D, and Hense HW (2011) Determinants of macular pigment optical density and its relation to age-related maculopathy: results from the Muenster Aging and Retina Study (MARS). Invest Ophthalmol Vis Sci 52:3452-7.

[61] Weigert G, Kaya S, Pemp B, Sacu S, Lasta M, Werkmeister RM, Dragostinoff N, Simader C, Garhofer G, Schmidt-Erfurth U, and Schmetterer L (2011) Effects of lutein 
supplementation on macular pigment optical density and visual acuity in patients with age-related macular degeneration. Invest Ophthalmol Vis Sci.

[62] Trumbo PR and Ellwood KC (2006) Lutein and zeaxanthin intakes and risk of agerelated macular degeneration and cataracts: an evaluation using the Food and Drug Administration's evidence-based review system for health claims. Am J Clin Nutr 84:971-4.

[63] Neelam K, Hogg RE, Stevenson MR, Johnston E, Anderson R, Beatty S, and Chakravarthy U (2008) Carotenoids and co-antioxidants in age-related maculopathy: design and methods. Ophthalmic Epidemiol 15:389-401.

[64] Alves-Rodrigues A and Shao A (2004) The science behind lutein. Toxicol Lett 150:57-83.

[65] Dagnelie G, Zorge IS, and McDonald TM (2000) Lutein improves visual function in some patients with retinal degeneration: a pilot study via the Internet. Optometry 71:147-64.

[66] Shao A and Hathcock JN (2006) Risk assessment for the carotenoids lutein and lycopene. Regul Toxicol Pharmacol 45:289-98.

[67] Padayatty SJ, Katz A, Wang Y, Eck P, Kwon O, Lee JH, Chen S, Corpe C, Dutta A, Dutta SK, and Levine M (2003) Vitamin C as an antioxidant: evaluation of its role in disease prevention. Journal of the American College of Nutrition 22:18-35.

[68] McGregor GP and Biesalski HK (2006) Rationale and impact of vitamin C in clinical nutrition. Current opinion in clinical nutrition and metabolic care 9:697-703.

[69] Alvarez RA, Liou GI, Fong SL, and Bridges CD (1987) Levels of alpha- and gammatocopherol in human eyes: evaluation of the possible role of IRBP in intraocular alpha-tocopherol transport. Am J Clin Nutr 46:481-7.

[70] Handelman GJ, Machlin LJ, Fitch K, Weiter JJ, and Dratz EA (1985) Oral alphatocopherol supplements decrease plasma gamma-tocopherol levels in humans. $J$ Nutr 115:807-13.

[71] Mares-Perlman JA, Klein R, Klein BE, Greger JL, Brady WE, Palta M, and Ritter LL (1996) Association of zinc and antioxidant nutrients with age-related maculopathy. Arch Ophthalmol 114:991-7.

[72] SanGiovanni JP, Chew EY, Clemons TE, Ferris FL, 3rd, Gensler G, Lindblad AS, Milton RC, Seddon JM, and Sperduto RD (2007) The relationship of dietary carotenoid and vitamin $\mathrm{A}, \mathrm{E}$, and $\mathrm{C}$ intake with age-related macular degeneration in a case-control study: AREDS Report No. 22. Arch Ophthalmol 125:1225-32.

[73] Klein BE, Knudtson MD, Lee KE, Reinke JO, Danforth LG, Wealti AM, Moore E, and Klein R (2008) Supplements and age-related eye conditions the beaver dam eye study. Ophthalmology 115:1203-8.

[74] Taylor HR, Tikellis G, Robman LD, McCarty CA, and McNeil JJ (2002) Vitamin E supplementation and macular degeneration: randomised controlled trial. BMJ 325:11.

[75] Christen WG, Glynn RJ, Chew EY, and Buring JE (2010) Vitamin E and age-related macular degeneration in a randomized trial of women. Ophthalmology 117:1163-8.

[76] Keilin D and Mann T (1940) Carbonic anhydrase. Purification and nature of the enzyme. The Biochemical journal 34:1163-76.

[77] Vallee BL and Auld DS (1990) Zinc coordination, function, and structure of zinc enzymes and other proteins. Biochemistry 29:5647-59. 
[78] Coleman JE (1992) Zinc proteins: enzymes, storage proteins, transcription factors, and replication proteins. Annual review of biochemistry 61:897-946.

[79] Berg JM and Shi Y (1996) The galvanization of biology: a growing appreciation for the roles of zinc. Science 271:1081-5.

[80] Nriagu J, Zinc Deficiency in Human Health, in Encyclopedia of Environmental Health, C. Editor in, xA, and O.N. Jerome, Editors. 2011, Elsevier: Burlington. p. 789-800.

[81] Aggett PJ and Comerford JG (1995) Zinc and human health. Nutr Rev 53:S16-22.

[82] Galin MA, Nano HD, and Hall T (1962) Ocular zinc concentration. Investigative ophthalmology 1:142-8.

[83] Karcioglu ZA (1982) Zinc in the eye. Surv Ophthalmol 27:114-22.

[84] Grahn BH, Paterson PG, Gottschall-Pass KT, and Zhang Z (2001) Zinc and the eye. J Am Coll of Nutr 20:106-18.

[85] Solomons NW and Russell RM (1980) The interaction of vitamin A and zinc: implications for human nutrition. Am J Clin Nutr 33:2031-40.

[86] Wagner PA (1985) Zinc nutriture in the elderly. Geriatrics 40:111-3, 117-8, 124-5.

[87] Stur M, Tittl M, Reitner A, and Meisinger V (1996) Oral zinc and the second eye in agerelated macular degeneration. Invest Ophthalmol Vis Sci 37:1225-35.

[88] Cho E, Stampfer MJ, Seddon JM, Hung S, Spiegelman D, Rimm EB, Willett WC, and Hankinson SE (2001) Prospective Study of Zinc Intake and the Risk of Age-Related Macular Degeneration. Ann Epidemiol 11:328-336.

[89] Evans J (2008) Antioxidant supplements to prevent or slow down the progression of AMD: a systematic review and meta-analysis. Eye 22:751-60.

[90] Klein ML, Francis PJ, Rosner B, Reynolds R, Hamon SC, Schultz DW, Ott J, and Seddon JM (2008) CFH and LOC387715/ARMS2 genotypes and treatment with antioxidants and zinc for age-related macular degeneration. Ophthalmology 115:1019-25.

[91] Ho L, van Leeuwen R, Witteman JC, van Duijn CM, Uitterlinden AG, Hofman A, de Jong PT, Vingerling JR, and Klaver CC (2011) Reducing the genetic risk of agerelated macular degeneration with dietary antioxidants, zinc, and omega-3 fatty acids: the Rotterdam study. Arch Ophthalmol 129:758-66.

[92] Johnson AR, Munoz A, Gottlieb JL, and Jarrard DF (2007) High dose zinc increases hospital admissions due to genitourinary complications. J Urol 177:639-43.

[93] Kishan AU, Modjtahedi BS, Martins EN, Modjtahedi SP, and Morse LS (2011) Lipids and age-related macular degeneration. Survey of ophthalmology 56:195-213.

[94] Fliesler SJ and Anderson RE (1983) Chemistry and metabolism of lipids in the vertebrate retina. Progress in lipid research 22:79-131.

[95] Rotstein NP, Aveldano MI, Barrantes FJ, and Politi LE (1996) Docosahexaenoic acid is required for the survival of rat retinal photoreceptors in vitro. J Neurochem 66:18519.

[96] Rotstein NP, Aveldano MI, Barrantes FJ, Roccamo AM, and Politi LE (1997) Apoptosis of retinal photoreceptors during development in vitro: protective effect of docosahexaenoic acid. J Neurochem 69:504-13.

[97] Politi L, Rotstein N, and Carri N (2001) Effects of docosahexaenoic acid on retinal development: cellular and molecular aspects. Lipids 36:927-35. 
[98] Politi LE, Rotstein NP, and Carri NG (2001) Effect of GDNF on neuroblast proliferation and photoreceptor survival: additive protection with docosahexaenoic acid. Invest Ophthalmol Vis Sci 42:3008-15.

[99] Litman BJ, Niu SL, Polozova A, and Mitchell DC (2001) The role of docosahexaenoic acid containing phospholipids in modulating $G$ protein-coupled signaling pathways: visual transduction. J Mol Neurosci 16:237-42; discussion 279-84.

[100] Gibson NJ and Brown MF (1993) Lipid headgroup and acyl chain composition modulate the MI-MII equilibrium of rhodopsin in recombinant membranes. Biochemistry 32:2438-54.

[101] Brown MF (1994) Modulation of rhodopsin function by properties of the membrane bilayer. Chem Phys Lipids 73:159-80.

[102] Neuringer M, Connor WE, Van Petten C, and Barstad L (1984) Dietary omega-3 fatty acid deficiency and visual loss in infant rhesus monkeys. J Clin Invest 73:272-6.

[103] Neuringer M, Connor WE, Lin DS, Barstad L, and Luck S (1986) Biochemical and functional effects of prenatal and postnatal omega 3 fatty acid deficiency on retina and brain in rhesus monkeys. Proc Natl Acad Sci U S A 83:4021-5.

[104] MacDonald IM, Hebert M, Yau RJ, Flynn S, Jumpsen J, Suh M, and Clandinin MT (2004) Effect of docosahexaenoic acid supplementation on retinal function in a patient with autosomal dominant Stargardt-like retinal dystrophy. Br J Ophthalmol 88:305-6.

[105] James MJ, Gibson RA, and Cleland LG (2000) Dietary polyunsaturated fatty acids and inflammatory mediator production. Am J Clin Nutr 71:343S-8S.

[106] Mares-Perlman JA, Brady WE, Klein R, VandenLangenberg GM, Klein BE, and Palta M (1995) Dietary fat and age-related maculopathy. Arch Ophthalmol 113:743-8.

[107] Smith W, Mitchell P, and Leeder SR (2000) Dietary fat and fish intake and age-related maculopathy. Arch Ophthalmol 118:401-4.

[108] Cho E, Hung S, Willett WC, Spiegelman D, Rimm EB, Seddon JM, Colditz GA, and Hankinson SE (2001) Prospective study of dietary fat and the risk of age-related macular degeneration. Am J Clin Nutr 73:209-18.

[109] Seddon JM, Rosner B, Sperduto RD, Yannuzzi L, Haller JA, Blair NP, and Willett W (2001) Dietary fat and risk for advanced age-related macular degeneration. Arch Ophthalmol 119:1191-9.

[110] Chua B, Flood V, Rochtchina E, Wang JJ, Smith W, and Mitchell P (2006) Dietary fatty acids and the 5-year incidence of age-related maculopathy. Arch Ophthalmol 124:981-6.

[111] Seddon JM, George S, and Rosner B (2006) Cigarette smoking, fish consumption, omega-3 fatty acid intake, and associations with age-related macular degeneration: the US Twin Study of Age-Related Macular Degeneration. Arch Ophthalmol 124:9951001.

[112] Delcourt C, Carriere I, Cristol JP, Lacroux A, and Gerber M (2007) Dietary fat and the risk of age-related maculopathy: the POLANUT study. Eur J Clin Nutr 61:1341-4.

[113] SanGiovanni JP, Chew EY, Clemons TE, Davis MD, Ferris FL, 3rd, Gensler GR, Kurinij N, Lindblad AS, Milton RC, Seddon JM, and Sperduto RD (2007) The relationship of dietary lipid intake and age-related macular degeneration in a case-control study: AREDS Report No. 20. Arch Ophthalmol 125:671-9. 
[114] Augood C, Chakravarthy U, Young I, Vioque J, de Jong PT, Bentham G, Rahu M, Seland J, Soubrane G, Tomazzoli L, Topouzis F, Vingerling JR, and Fletcher AE (2008) Oily fish consumption, dietary docosahexaenoic acid and eicosapentaenoic acid intakes, and associations with neovascular age-related macular degeneration. Am J Clin Nutr 88:398-406.

[115] SanGiovanni JP, Chew EY, Agron E, Clemons TE, Ferris FL, 3rd, Gensler G, Lindblad AS, Milton RC, Seddon JM, Klein R, and Sperduto RD (2008) The relationship of dietary omega-3 long-chain polyunsaturated fatty acid intake with incident agerelated macular degeneration: AREDS report no. 23. Arch Ophthalmol 126:1274-9.

[116] Tan JS, Wang JJ, Flood V, and Mitchell P (2009) Dietary fatty acids and the 10-year incidence of age-related macular degeneration: the Blue Mountains Eye Study. Arch Ophthalmol 127:656-65.

[117] Wang JJ, Rochtchina E, Smith W, Klein R, Klein BE, Joshi T, Sivakumaran TA, Iyengar S, and Mitchell P (2009) Combined effects of complement factor $\mathrm{H}$ genotypes, fish consumption, and inflammatory markers on long-term risk for age-related macular degeneration in a cohort. Am J Epidemiol 169:633-41.

[118] Chong EW, Kreis AJ, Wong TY, Simpson JA, and Guymer RH (2008) Dietary omega-3 fatty acid and fish intake in the primary prevention of age-related macular degeneration: a systematic review and meta-analysis. Arch Ophthalmol 126:826-33.

[119] Hodge WG, Schachter HM, Barnes D, Pan Y, Lowcock EC, Zhang L, Sampson M, Morrison A, Tran K, Miguelez M, and Lewin G (2006) Efficacy of omega-3 fatty acids in preventing age-related macular degeneration: a systematic review. Ophthalmology 113:1165-72; quiz 1172-3, 1178.

[120] Collaboration HLT (2005) Dose-dependent effects of folic acid on blood concentrations of homocysteine: a meta-analysis of the randomized trials. Am J Clin Nutr 82:806-12.

[121] Heuberger RA, Fisher AI, Jacques PF, Klein R, Klein BE, Palta M, and Mares-Perlman JA (2002) Relation of blood homocysteine and its nutritional determinants to agerelated maculopathy in the third National Health and Nutrition Examination Survey. Am J Clin Nutr 76:897-902.

[122] Axer-Siegel R, Bourla D, Ehrlich R, Dotan G, Benjamini Y, Gavendo S, Weinberger D, and Sela BA (2004) Association of neovascular age-related macular degeneration and hyperhomocysteinemia. Am J Ophthalmol 137:84-9.

[123] Rochtchina E, Wang JJ, Flood VM, and Mitchell P (2007) Elevated serum homocysteine, low serum vitamin B12, folate, and age-related macular degeneration: the Blue Mountains Eye Study. Am J Ophthalmol 143:344-6.

[124] Nowak M, Swietochowska E, Wielkoszynski T, Marek B, Kos-Kudla B, Szapska B, Kajdaniuk D, Glogowska-Szelag J, Sieminska L, Ostrowska Z, Koziol H, and Klimek J (2005) Homocysteine, vitamin B12, and folic acid in age-related macular degeneration. Eur J Ophthalmol 15:764-7.

[125] Vine AK, Stader J, Branham K, Musch DC, and Swaroop A (2005) Biomarkers of cardiovascular disease as risk factors for age-related macular degeneration. Ophthalmology 112:2076-80.

[126] Coral K, Raman R, Rathi S, Rajesh M, Sulochana KN, Angayarkanni N, Paul PG, and Ramakrishnan S (2006) Plasma homocysteine and total thiol content in patients with exudative age-related macular degeneration. Eye 20:203-7. 
[127] Kamburoglu G, Gumus K, Kadayifcilar S, and Eldem B (2006) Plasma homocysteine, vitamin B12 and folate levels in age-related macular degeneration. Graefes Arch Clin Exp Ophthalmol 244:565-9.

[128] Seddon JM, Gensler G, Klein ML, and Milton RC (2006) Evaluation of plasma homocysteine and risk of age-related macular degeneration. Am J Ophthalmol 141:201-3.

[129] Domagala TB, Undas A, Libura M, and Szczeklik A (1998) Pathogenesis of vascular disease in hyperhomocysteinaemia. J Cardiovasc Risk 5:239-47.

[130] Chambers JC, Obeid OA, and Kooner JS (1999) Physiological increments in plasma homocysteine induce vascular endothelial dysfunction in normal human subjects. Arterioscler Thromb Vasc Biol 19:2922-7.

[131] McDowell IF and Lang D (2000) Homocysteine and endothelial dysfunction: a link with cardiovascular disease. J Nutr 130:369S-372S.

[132] Christen WG, Glynn RJ, Chew EY, Albert CM, and Manson JE (2009) Folic acid, pyridoxine, and cyanocobalamin combination treatment and age-related macular degeneration in women: the Women's Antioxidant and Folic Acid Cardiovascular Study. Arch Intern Med 169:335-41.

[133] Prior RL, Cao G, Martin A, Sofic E, McEwen J, O'Brien C, Lischner N, Ehlenfeldt M, Kalt W, Krewer G, and Mainland CM (1998) Antioxidant Capacity As Influenced by Total Phenolic and Anthocyanin Content, Maturity, and Variety of Vaccinium Species. Journal of Agricultural and Food Chemistry 46:2686-2693.

[134] Cao G, Sofic E, and Prior RL (1996) Antioxidant Capacity of Tea and Common Vegetables. Journal of Agricultural and Food Chemistry 44:3426-3431.

[135] Wang H, Cao G, and Prior RL (1996) Total Antioxidant Capacity of Fruits. Journal of Agricultural and Food Chemistry 44:701-705.

[136] De Rosso VV, Moran Vieyra FE, Mercadante AZ, and Borsarelli CD (2008) Singlet oxygen quenching by anthocyanin's flavylium cations. Free radical research 42:88591.

[137] Liakopoulos G, Nikolopoulos D, Klouvatou A, Vekkos KA, Manetas Y, and Karabourniotis G (2006) The photoprotective role of epidermal anthocyanins and surface pubescence in young leaves of grapevine (Vitis vinifera). Annals of botany 98:257-65.

[138] Bagchi D, Sen CK, Bagchi M, and Atalay M (2004) Anti-angiogenic, antioxidant, and anti-carcinogenic properties of a novel anthocyanin-rich berry extract formula. Biochemistry. Biokhimiia 69:75-80, 1 p preceding 75.

[139] Bagchi D, Roy S, Patel V, He G, Khanna S, Ojha N, Phillips C, Ghosh S, Bagchi M, and Sen CK (2006) Safety and whole-body antioxidant potential of a novel anthocyaninrich formulation of edible berries. Molecular and cellular biochemistry 281:197-209.

[140] Sadilova E, Carle R, and Stintzing FC (2007) Thermal degradation of anthocyanins and its impact on color and in vitro antioxidant capacity. Molecular nutrition $\mathcal{E}$ food research 51:1461-71.

[141] Seeram NP (2008) Berry Fruits: Compositional Elements, Biochemical Activities, and the Impact of Their Intake on Human Health, Performance, and Disease. J Agric Food Chem 56:627-629. 
[142] Chang RC and So KF (2008) Use of anti-aging herbal medicine, Lycium barbarum, against aging-associated diseases. What do we know so far? Cell Mol Neurobiol 28:643-52.

[143] Li SY, Yang D, Yeung CM, Yu WY, Chang RC, So KF, Wong D, and Lo AC (2011) Lycium barbarum polysaccharides reduce neuronal damage, blood-retinal barrier disruption and oxidative stress in retinal ischemia/reperfusion injury. PLoS One 6:e16380.

[144] Ho YS, So KF, and Chang RC (2010) Anti-aging herbal medicine--how and why can they be used in aging-associated neurodegenerative diseases? Ageing Res Rev 9:35462.

[145] Heuberger RA, Mares-Perlman JA, Klein R, Klein BE, Millen AE, and Palta M (2001) Relationship of dietary fat to age-related maculopathy in the Third National Health and Nutrition Examination Survey. Arch Ophthalmol 119:1833-8.

[146] Chiu CJ, Milton RC, Klein R, Gensler G, and Taylor A (2009) Dietary compound score and risk of age-related macular degeneration in the age-related eye disease study. Ophthalmology 116:939-46. 


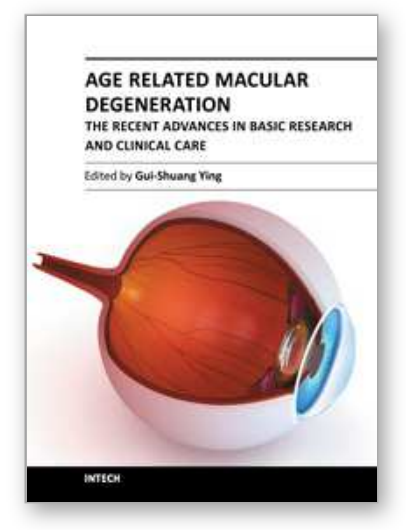

\author{
Age Related Macular Degeneration - The Recent Advances in Basic \\ Research and Clinical Care \\ Edited by Dr. Gui-Shuang Ying
}

ISBN 978-953-307-864-9

Hard cover, 300 pages

Publisher InTech

Published online 20, January, 2012

Published in print edition January, 2012

Age-related Macular Degeneration (AMD) is the leading cause of vision loss and blindness in the developed countries. In the past decade, great progress has been made in understanding the pathobiology and genetics of this blinding disease, as well as in finding new therapies for its treatment. These include the discovery of several genes that are associated with the risk of AMD, new anti-VEGF treatments for wet AMD and new imaging techniques to diagnose and monitor the AMD. All chapters in this book were contributed by outstanding research scientists and clinicians in the area of AMD. I hope this timely book will provide the basic scientists and clinicians with an opportunity to learn about the recent advances in the field of AMD.

\title{
How to reference
}

In order to correctly reference this scholarly work, feel free to copy and paste the following:

Amy C. Y. Lo and lan Y. Wong (2012). Nutritional Supplement Use and Age-Related Macular Degeneration, Age Related Macular Degeneration - The Recent Advances in Basic Research and Clinical Care, Dr. GuiShuang Ying (Ed.), ISBN: 978-953-307-864-9, InTech, Available from: http://www.intechopen.com/books/agerelated-macular-degeneration-the-recent-advances-in-basic-research-and-clinical-care/nutritional-supplementuse-and-age-related-macular-degeneration

\section{INTECH}

open science | open minds

\section{InTech Europe}

University Campus STeP Ri

Slavka Krautzeka 83/A

51000 Rijeka, Croatia

Phone: +385 (51) 770447

Fax: +385 (51) 686166

www.intechopen.com

\section{InTech China}

Unit 405, Office Block, Hotel Equatorial Shanghai

No.65, Yan An Road (West), Shanghai, 200040, China

中国上海市延安西路65号上海国际贵都大饭店办公楼 405 单元

Phone: +86-21-62489820

Fax: $+86-21-62489821$ 
(C) 2012 The Author(s). Licensee IntechOpen. This is an open access article distributed under the terms of the Creative Commons Attribution 3.0 License, which permits unrestricted use, distribution, and reproduction in any medium, provided the original work is properly cited. 